\title{
Comparative study of thermal gelation properties and molecular forces of actomyosin extracted from normal and pale, soft and exudative-like chicken breast meat
}

\author{
Ke Li' ${ }^{1}$, Jun-Ya Liu', Lei Fu', Ying-Ying Zhao', and Yan-Hong Bai ${ }^{1}{ }^{1} *$
}

\begin{abstract}
* Corresponding Author: Yan-Hong Bai Tel: +86-15238396169, Fax: +86-0371-86609632, E-mail: baiyanhong212@163.com
\end{abstract}

'College of Food and Bioengineering, Zhengzhou University of Light Industry, Henan Collaborative Innovation Center for Food Production and Safety, Henan Key Laboratory of Cold Chain Food Quality and Safety Control, Zhengzhou 450001, China

ORCID

Ke Li

https://orcid.org/0000-0001-8572-1103 Jun-Ya Liu

https://orcid.org/0000-0001-6845-8470 Lei Fu

https://orcid.org/0000-0002-5564-3324 Ying-Ying Zhao

https://orcid.org/0000-0002-7235-2836

Yan-Hong Bai

https://orcid.org/0000-0002-2074-0351

Submitted May 22, 2018; Revised Jul 11, 2018; Accepted Aug 28, 2018
Objective: The objectives of this study were to investigate the thermal gelation properties and molecular forces of actomyosin extracted from two classes of chicken breast meat qualities (normal and pale, soft and exudative [PSE]-like) during heating process to further improve the understanding of the variations of functional properties between normal and PSE-like chicken breast meat.

Methods: Actomyosin was extracted from normal and PSE-like chicken breast meat and the gel strength, water-holding capacity (WHC), protein loss, particle size and distribution, dynamic rheology and protein thermal stability were determined, then turbidity, active sulfhydryl group contents, hydrophobicity and molecular forces during thermal-induced gelling formation were comparatively studied.

Results: Sodium dodecyl sulphate-polyacrylamide gel electrophoresis showed that protein profiles of actomyosin extracted from normal and PSE-like meat were not significantly different ( $p>0.05)$. Compared with normal actomyosin, PSE-like actomyosin had lower gel strength, WHC, particle size, less protein content involved in thermal gelation forming $(\mathrm{p}<0.05)$, and reduced onset temperature $\left(T_{o}\right)$, thermal transition temperature $\left(T_{d}\right)$, storage modulus $\left(G^{\prime}\right)$ and loss modulus $\left(\mathrm{G}^{\prime \prime}\right)$. The turbidity, reactive sulfhydryl group of PSE-like actomyosin were higher when heated from $40^{\circ} \mathrm{C}$ to $60^{\circ} \mathrm{C}$. Further heating to $80^{\circ} \mathrm{C}$ had lower transition from reactive sulfhydryl group into a disulfide bond and surface hydrophobicity. Molecular forces showed that hydrophobic interaction was the main force for heat-induced gel formation while both ionic and hydrogen bonds were different significantly between normal and PSE-like actomyosin $(\mathrm{p}<0.05)$.

Conclusion: These changes in chemical groups and inter-molecular bonds affected proteinprotein interaction and protein-water interaction and contributed to the inferior thermal gelation properties of PSE-like meat.

Keywords: Pale, Soft and Exudative (PSE)-like; Chicken; Actomyosin; Gel Properties; Molecular Forces

\section{INTRODUCTION}

Pale, soft and exudative (PSE)-like poultry meat continues to occur at a high incidence and is a main quality defect in commercial poultry plants, which results in great economic losses to the poultry industry [1]. This meat quality defect affects the sensory quality and consumer's purchase intentions, and heat-induced gelation ability, water-holding capacity (WHC), emulsion capability, consequently textural characteristic and cooking yield when used in further processed poultry meat products [2]. Petracci et al [3] pointed out that it has become one of large challenges in the research of functional properties of meat proteins for the poultry industry worldwide. These inferior functionalities of meat products are closely related to 
the denatured state and structural changes of muscle proteins [4]. Previous studies usually focused on the frequency of PSElike occurrence and evaluated the differences in the solubility of salt soluble proteins between normal and PSE-like meat to indicate the level of denaturation of PSE-like meat proteins $[1,5]$. Barbut [6] investigating the effects of different chicken meat qualities on the extractable proteins, found that PSE-like meat had lower salt soluble proteins than that of normal meat, and the $151-\mathrm{kDa}$ band was not observed by sodium dodecyl sulphate-polyacrylamide gel electrophoresis (SDS-PAGE), suggesting the lower functionalities of PSE-like meat was attributed to the excessive denaturation of myofibrillar proteins. It is well known that myofibrillar proteins, mainly containing myosin and actin, are the major proteins responsible for thermal gelling formation, which play an important role in texture and WHC of meat products [7]. The dominant myofibrillar proteins are in the form of actomyosin for post-rigor muscles [8]. The physicochemical properties and mechanisms of thermallyinduced gelation of myofibrillar proteins extracted from normal meat have been clearly demonstrated [7,9]. However, little information is available concerning the denatured state and thermal gelling formation of PSE-like poultry meat proteins. Only few studies reported the phyco-chemical changes in salt soluble proteins or actomyosin extracted from PSE pork [10, 11]. The basic knowledge of the impaired performance of PSElike poultry meat proteins are not clearly understood.

In general, many studies concerned salt soluble proteins extraction $[3,5]$. The reasons for unsuitable gelling properties of proteins from PSE-like meat were mostly explained based on the lower solubility of proteins. The functional properties of proteins in PSE-like meat have not been studied sufficiently for understanding of the factors that influence the functional characteristics of PSE-like meat. It was usually considered that lower protein solubility or less protein extraction were induced by faster glycolysis rate and lower $\mathrm{pH}$ of PSE-like meat during rigor development or ionic strength conditions [1,12]. According to our previous studies $[5,12]$, the major factors leading to PSE-like meat having poor protein functionalities are concluded as protein conformation, characteristic of salt soluble proteins, myosin and actin denaturation during meat processing, which also depend on $\mathrm{pH}$ and ionic strength conditions. In addition, a three-dimensional network gel is formed by the cross-linking of proteins during heating process, which is based on the strength of different molecular forces such as ionic bonds, hydrogen bonds, hydrophobic interactions $[13,14]$. Ni et al $[15]$ reported that different $\mathrm{pH}$ values affected the charge quantity and regulated the main molecular forces during heat-induced gels formation. A further understanding of changes in the molecular forces of PSE-like chicken meat intrinsic proteins during heating process could be useful to explain the mechanisms in the impaired functional properties of PSE-like chicken meat. Importantly, it is necessary to ex- tract major proteins (actomyosin) and adjust the unified protein concentration, $\mathrm{pH}$ and other external factors to compare the molecular functionality and enable an in-depth understanding of the factors that influence the functional characteristics of PSE-like meat.

Therefore, the objectives of this study were to: i) evaluate the thermal gelation properties and level of thermal protein denaturation of actomyosin extracted from normal and PSElike chicken breast meat, and ii) investigate changes in the molecular forces during thermal-induced gelling formation to further improve the understanding of the variations of functional properties between normal and PSE-like chicken breast meat.

\section{MATERIALS AND METHODS}

\section{Chicken breast meat selection}

Broiler chicken breast ( $M$. Pectoralis major) muscles were obtained from a commercial meat plant (Liu-he Group, Tai-an, Shan-dong, China). The average Arbor Acre broilers' age was $45.2 \pm 2.2$ days and the average body weight was $2.19 \pm 0.41 \mathrm{~kg}$. Briefly, selection and classification of normal and PSE-like chicken meat (a total of 60 normal and PSE-like chicken meat that were collected on three different occasions) using color and $\mathrm{pH}$ measurements were according to Li et al [12]. The criteria values for PSE-like meat $\left(\mathrm{L}^{*}>53, \mathrm{pH}_{24 \mathrm{~h}}<5.7\right)$ and normal meat $\left(46<\mathrm{L}^{*}<53,5.7<\mathrm{H}_{24 \mathrm{~h}}<6.1\right)$ were based on the lightness $\left(\mathrm{L}^{*}\right)$ and $\mathrm{pH}$ value as reported by $\mathrm{Li}$ et al [12]. After selection, all skin, fat and the visible connective tissue was trimmed off the chicken breast meat. Then, all samples within each group were cut into cubes (about $1 \mathrm{~cm} \times 1 \mathrm{~cm} \times 1 \mathrm{~cm}$ ) and mixed, then tagged, put in plastic bags and frozen $\left(-20^{\circ} \mathrm{C}\right)$, and were utilized within two weeks.

\section{Meat quality measurements}

Briefly, the $\mathrm{L}^{*}$ values of each chicken breast meat were determined in triplicate using a chromameter (Minolta Camera Co., Osaka, Japan) as described by Li et al [5]. The $\mathrm{pH}$ values were measured by inserting an electrode of a portable $\mathrm{pH}$ meter (Orion 3-star, Dallas, TX, USA) at three different locations of each breast meat [12]. Drip loss of meat was evaluated at $24 \mathrm{~h}$ postmortem. Each breast meat (about $20 \mathrm{~g}$ ) was placed in a sealed polyethylene package and kept at $4^{\circ} \mathrm{C}$ for $24 \mathrm{~h}$. Drip loss was expressed as a percentage of the weight loss over initial meat sample weight.

\section{Extraction of actomyosin}

Actomyosin was extracted from both normal and PSE-like meat according to the method of Ogawa et al [16] with minor modifications. Normal and PSE-like meat were thawed at $0^{\circ} \mathrm{C}$ to $4^{\circ} \mathrm{C}$ for $24 \mathrm{~h}$ prior to extraction. The thawed meat samples were ground three times in a Waring Blender (GM200, Restch, 
Haan, Germany) at 3,000 r/min for $10 \mathrm{~s}$. The ground samples (approximately $80 \mathrm{~g}$ ) were suspended in $300 \mathrm{~mL}$ of ice-cold isolation buffer $\left(50 \mathrm{mM} \mathrm{KCl}, 20 \mathrm{mM} \mathrm{K} \mathrm{HPO}_{4} / \mathrm{KH}_{2} \mathrm{PO}_{4}, \mathrm{pH}\right.$ 7.0), homogenized (Ultraturrax T25, IKA, Staufen, Germany) two times for $30 \mathrm{~s}$ at $10,000 \mathrm{r} / \mathrm{min}$ and were filtered through a 20-mesh sieve (aperture $0.9 \mathrm{~mm}$ ). The suspension was centrifuged (Beckman Avanti J-E, Beckman Coulter, Miami, FL, USA) at 10,000 $\mathrm{g}$ for $5 \mathrm{~min}$ at $4^{\circ} \mathrm{C}$. The pellet was collected. These procedures were repeated once. Next, the obtained pellet was homogenized two times for $30 \mathrm{~s}$ at 10,000 r/min in $300 \mathrm{~mL}$ of chilled $0.6 \mathrm{M} \mathrm{KCl}$ buffer $(0.6 \mathrm{M} \mathrm{KCl}, 20 \mathrm{mM}$ $\mathrm{K}_{2} \mathrm{HPO}_{4} / \mathrm{KH}_{2} \mathrm{PO}_{4}, \mathrm{pH}$ 7.0). The suspension was centrifuged at 10,000 for $5 \mathrm{~min}$. The supernatant was filtered through a 20-mesh sieve. Then, the supernatant was blended in $1.2 \mathrm{~L}$ of $20 \mathrm{mM}$ potassium phosphate buffer $\left(20 \mathrm{mM} \mathrm{K}_{2} \mathrm{HPO}_{4} / \mathrm{KH}_{2} \mathrm{PO}_{4}\right.$, $\mathrm{pH}$ 7.0). The precipitate was collected by centrifugation at $10,000 \mathrm{~g} \times 10 \mathrm{~min}$ and then suspended in $150 \mathrm{~mL}$ of ice-cold isolation buffer $\left(50 \mathrm{mM} \mathrm{KCl}, 20 \mathrm{mM} \mathrm{K}_{2} \mathrm{HPO}_{4} / \mathrm{KH}_{2} \mathrm{PO}_{4}, \mathrm{pH}\right.$ 7.0). The washed precipitate was collected by centrifugation at $10,000 \mathrm{~g}$ for $10 \mathrm{~min}$. All procedures were carried out at $4^{\circ} \mathrm{C}$. The pellet from the final centrifugation step was collected as actomyosin. The actomyosin concentration was determined by the Biuret method [17]. Actomyosin was stored at $4^{\circ} \mathrm{C}$ and used in the succeeding tests.

\section{Sodium dodecyl sulphate-polyacrylamide gel electrophoresis}

Actomyosin extracted from normal and PSE-like meat was diluted to $3 \mathrm{mg} / \mathrm{mL}$ with buffer (10\% $\beta$-mercaptoethanol and $0.001 \%$ bromophenol blue, $125 \mathrm{mM}$ Tris, $4 \%$ SDS, $20 \%$ glycerol). Each sample was mixed well and boiled at $95^{\circ} \mathrm{C}$ for 3 $\mathrm{min}$. The gel was loaded with $15 \mu \mathrm{g}$ per well of sample solution. SDS-PAGE was performed using a 10\% acrylamide resolving gel and a $4 \%$ acrylamide stacking gel according to the method of Laemmli [18]. After electrophoresis, the gel was stained for the proteins using a solution containing $0.1 \%(\mathrm{w} / \mathrm{v})$ Coomassie brilliant blue R-250, 40\% (v/v) ethanol, and 7\% (v/v) glacial acetic acid. Subsequent to destaining, the gels were scanned (GT-800F, Epson, Hirookanomura, Japan).

\section{Particle size and distribution}

Particle size distribution measurement was determined according to the method of Li et al [19] with slight modifications. The particle size of actomyosin was determined by static light scattering using a Mastersizer 2000 laser light scattering analyzer (Malvern Instruments Ltd., Malvern, UK). Normal and PSE-like actomyosin were stirred and dispersed in potassium phosphate buffer solution with two different $\mathrm{KCl}$ concentrations $\left(50 \mathrm{mM} \mathrm{KCl}\right.$ or $0.6 \mathrm{M} \mathrm{KCl}, 20 \mathrm{mM} \mathrm{K} \mathrm{HPO}_{4} / \mathrm{KH}_{2} \mathrm{PO}_{4}$, $\mathrm{pH}$ 7.0), respectively. The particle distribution of each sample was monitored over four successive readings. The particle size was expressed as $\mathrm{D}_{50}, \mathrm{D}_{90}, \mathrm{D}_{3,2}$, and $\mathrm{D}_{4,3}$ as follows:
$\mathrm{D}_{50 \%}$, the size of the particle for which $50 \%$ of the sample is below this size;

$D_{90 \%}$, the size of the particle for which $90 \%$ of the sample is below this size;

$\mathrm{D}_{(3,2)}$, the surface area moment mean diameter, $\mathrm{D}_{(3,2)}=$ $\sum \mathrm{n}_{\mathrm{i}} \mathrm{d}_{\mathrm{i}}^{3} / \sum \mathrm{n}_{\mathrm{i}} \mathrm{d}_{\mathrm{i}}^{2}$, where $\mathrm{n}_{\mathrm{i}}$ is the number of particles with diameter $\mathrm{d}_{\mathrm{i}}$ and was calculated from the size distribution;

$\mathrm{D}_{(4,3)}$, the volume moment mean diameter, $\mathrm{D}_{(4,3)}=\sum \mathrm{n}_{\mathrm{i}} \mathrm{d}_{\mathrm{i}}{ }^{4} /$ $\sum \mathrm{n}_{\mathrm{i}} \mathrm{d}_{\mathrm{i}}{ }^{3}$, where $\mathrm{n}_{\mathrm{i}}$ is the number of particles with diameter $\mathrm{d}_{\mathrm{i}}$ and was calculated from the size distribution.

\section{Gel strength}

Actomyosin extracted from normal and PSE-like meat was adjusted to $40 \mathrm{mg} / \mathrm{mL}$ using $0.6 \mathrm{M} \mathrm{KCl}$ buffer $(0.6 \mathrm{M} \mathrm{KCl}$, $\left.20 \mathrm{mM} \mathrm{K} \mathrm{HPO}_{4} / \mathrm{KH}_{2} \mathrm{PO}_{4}, \mathrm{pH} 7.0\right)$. Each sample (40 mg/mL) was added to a $10-\mathrm{mL}$ glass beaker $(25 \mathrm{~mm}$ diameter, $35 \mathrm{~mm}$ height). Then, the beakers were sealed with parafilm, heated and kept in a water bath (Julabo TW20, Gerhard-JuchheimStrasse, Germany) at $80^{\circ} \mathrm{C}$ for $20 \mathrm{~min}$. The gels were cooled in an ice bath and stored at $4^{\circ} \mathrm{C}$ overnight for analysis. The obtained gels were equilibrated to ambient temperature $\left(20^{\circ} \mathrm{C}\right)$. The strength of the gels was measured using a Texture Analyzer (TA.XT2i, Stable Micro Systems, Godalming, UK) according to the method of Chen et al [20] with slight modifications. The samples were subjected to a penetration test. $\mathrm{P} / 0.5$ probe was employed with $2.0 \mathrm{~mm} / \mathrm{s}$ pre-test speed, $1.0 \mathrm{~mm} / \mathrm{s}$ test speed and a $3 \mathrm{~g}$ trigger force. The penetration distance was $10 \mathrm{~mm}$. Gel strength was defined as the first peak force.

\section{Water-holding capacity of actomyosin}

The WHC of actomyosin was measured using a centrifugal method as described by Kocher and Foegeding [21] with a minor modification. The actomyosin (approximately $6 \mathrm{~g}$ ) was added to a $10-\mathrm{mL}$ centrifuge tube, heated and kept in a water bath (Julabo TW20, Germany) at $80^{\circ} \mathrm{C}$ for $20 \mathrm{~min}$, and then cooled to room temperature. The tubes were centrifuged at 10,000×g (Beckman Avanti J-E, Beckman Coulter, USA) for $10 \mathrm{~min}$. The original weight of actomyosin samples and the weight of the centrifuge tubes were recorded. Finally, the amount of liquid released was collected and measured. The WHC was calculated by the percentage of the amount of released water relative to the original weight of actomyosin samples (g). A low value demonstrates the gel has a superior WHC to the sample with a high value.

\section{Protein loss}

After determining the WHC of the gels, protein loss of each actomyosin gel was measured by the method as described by Camou and Sebranek [10]. A $1 \mathrm{~mL}$ aliquot of the released liquid from the gels was obtained, then the protein concentration 
was measured by the Biuret method [17].

\section{Differential scanning calorimetry}

Differential scanning calorimeter (Lindon, UT84042, TA Instruments, New Castle, DE, USA) was used to measure the onset $\left(\mathrm{T}_{\mathrm{o}}\right)$, maximum $\left(\mathrm{T}_{\mathrm{d}}\right)$, and endset $\left(\mathrm{T}_{\mathrm{e}}\right)$ temperatures for actomyosin endothermic transitions as well as denaturation enthalpy $(\Delta \mathrm{H})$ of actomyosin as described by Li et al [12] with slight modifications. $0.5 \mathrm{~g}$ of each sample was accurately weighed and kept at $20^{\circ} \mathrm{C}$ for $10 \mathrm{~min}$ in an aluminum pan. The thermal properties of actomyosin was determined by heating the samples in aluminum pans from $20^{\circ} \mathrm{C}$ to $85^{\circ} \mathrm{C}$ at $0.5^{\circ} \mathrm{C} / \mathrm{min}$. The supplied software (Thermal Analysis System 2000, Version 4.5A, TA Instruments, New Castle, DE, USA) was used to estimate these thermal parameters.

\section{Dynamic rheological measurements}

Dynamic rheological measurements of actomyosin were performed using a rheometer (Physica MCR 301, Anton Paar, Graz, Austria) equipped with a $25 \mathrm{~mm}$ parallel plate geometry in the oscillatory mode according to the method of Li et al [5]. The actomyosin $(40 \mathrm{mg} / \mathrm{mL})$ samples were placed and tempered between parallel plates with a $1 \mathrm{~mm}$ gap. Silicone oil was used to the edge of sample to prevent evaporation. Each sample was kept at $25^{\circ} \mathrm{C}$ for $3 \mathrm{~min}$, then heated from $25^{\circ} \mathrm{C}$ to $80^{\circ} \mathrm{C}$ at a scan rate of $1^{\circ} \mathrm{C} / \mathrm{min}$. The storage modulus $\left(\mathrm{G}^{\prime}\right)$ and loss modulus $\left(G^{\prime \prime}\right)$ of the samples were monitored during dynamic oscillatory measurements. $G^{\prime}$ was used to determine the energy stored resulting from elastic deformation of the gel network. $G^{\prime \prime}$ performed the viscous property of actomyosin samples during the gelatinization process.

\section{Turbidity}

Turbidity of actomyosin was determined as described by Wang et al [8] with some modifications. Each actomyosin sample was diluted to $2.5 \mathrm{mg} / \mathrm{mL}$ using $0.6 \mathrm{M} \mathrm{KCl}$ buffer $(0.6 \mathrm{M} \mathrm{KCl}$, $20 \mathrm{mM} \mathrm{K}_{2} \mathrm{HPO}_{4} / \mathrm{KH}_{2} \mathrm{PO}_{4}$, $\mathrm{pH} 7.0$ ) and measured by a UV/Vis spectrophotometer with a temperature control unit (Shimadzu, Nara-shi, Japan). The $0.6 \mathrm{M} \mathrm{KCl}$ buffer was used as a reference. Each sample was heated from $20^{\circ} \mathrm{C}$ to $85^{\circ} \mathrm{C}$ at $1^{\circ} \mathrm{C} / \mathrm{min}$ and the absorbance of each samples at 350 and $660 \mathrm{~nm}$ was determined and obtained once every $10^{\circ} \mathrm{C}$.

\section{Reactive sulfhydryl group}

The reactive sulfhydryl content was measured according to the method of Ellman [22] with slight modifications. Briefly, each actomyosin (normal and PSE-like actomyosin, respectively) was diluted to $2.0 \mathrm{mg} / \mathrm{mL}$ using $0.6 \mathrm{M} \mathrm{KCl}$ buffer. Then, $2 \mathrm{~mL}$ of each actomyosin solution $(2 \mathrm{mg} / \mathrm{mL})$ was placed in a $7-\mathrm{mL}$ centrifuge tube and heated in a water bath from $20^{\circ} \mathrm{C}$ to $85^{\circ} \mathrm{C}$ at $1^{\circ} \mathrm{C} / \mathrm{min}$. Twenty-one tubes were placed in water bath $(\mathrm{Ju}-$ labo TW20, Germany) for each actomyosin. Three tubes were taken out every $10^{\circ} \mathrm{C}$ intervals (total seven sampling points), then transformed in an ice water bath for $10 \mathrm{~min}$. Subsequently, $5 \mu \mathrm{L}$ of 5-5'-dithiobis-2-nitrobenzoic acid was added to the actomyosin solution and kept at room temperature for $20 \mathrm{~min}$. The absorbance of the actomyosin solution was determined at $412 \mathrm{~nm}$ (SpectraMax M $\mathrm{M}_{2}$, Molecular Devices Limited, Sunnyvale, CA, USA). Reactive sulfhydryl group content was calculated using the extinction coefficient of $13,600 \mathrm{M}^{-1} \mathrm{~cm}^{-1}$.

\section{Surface hydrophobicity}

The surface hydrophobicity of actomyosin was examined according to the method of Zhao et al [14] with slight modifications. Each actomyosin was diluted to $2.0 \mathrm{mg} / \mathrm{mL}$ using $0.6 \mathrm{M} \mathrm{KCl}$ buffer. Each actomyosin solution $(2 \mathrm{~mL})$ was placed in a $7-\mathrm{mL}$ centrifuge tube and heated in a water bath (Julabo TW20, Germany) from $20^{\circ} \mathrm{C}$ to $85^{\circ} \mathrm{C}$ at $1^{\circ} \mathrm{C} / \mathrm{min}$. Twentyone tubes were placed in water bath (Julabo TW20, Germany) for each actomyosin. Three tubes were taken out every $10^{\circ} \mathrm{C}$ intervals (total seven sampling points for each actomyosin), and then transformed in an ice water bath for $10 \mathrm{~min}$. Each actomyosin suspension $(2 \mathrm{~mL})$ was mixed with $80 \mu \mathrm{L}$ of bromophenol blue $(1 \mathrm{mg} / \mathrm{mL})(\mathrm{BPB})$. The $\mathrm{KCl}$ buffer $(0.6 \mathrm{M} \mathrm{KCl}$, $20 \mathrm{mM} \mathrm{K}_{2} \mathrm{HPO}_{4} / \mathrm{KH}_{2} \mathrm{PO}_{4}, \mathrm{pH} 7.0,2 \mathrm{~mL}$ ) with $80 \mu \mathrm{L}$ of BPB addition was used as the control. The control and samples were placed at $20^{\circ} \mathrm{C}$, mixed for $10 \mathrm{~min}$ and centrifuged at 4,000 g for 15 min (Beckman Avanti J-E, Beckman Coulter, USA). After centrifugation, the liquid supernatant was diluted 10 times. The absorbance of the control $\left(\mathrm{A}_{0}\right)$ and the sample $\left(\mathrm{A}_{\mathrm{s}}\right)$ were determined at $595 \mathrm{~nm}$. The $0.6 \mathrm{M} \mathrm{KCl}$ buffer was used as reference. The BPB bond content was expressed as the following equation: $\mathrm{BPB}$ bound $(\mu \mathrm{g})=80 \mu \mathrm{g} \times\left(\mathrm{A}_{0}-\mathrm{A}_{\mathrm{s}}\right) / \mathrm{A}_{\mathrm{o}}$.

\section{Molecular forces}

Molecular forces of actomyosin during heating process were determined as described by $\mathrm{Ni}$ et al [15]. Each of actomyosin sample $(1 \mathrm{~mL})$ was added to $10-\mathrm{mL}$ centrifuge tube. Each tube was heated from $20^{\circ} \mathrm{C}$ to $85^{\circ} \mathrm{C}$ at $1^{\circ} \mathrm{C} / \mathrm{min}$ in a water bath (Julabo TW20, Germany). The tube was taken out every $10^{\circ} \mathrm{C}$ intervals. Seven sampling points including $20^{\circ} \mathrm{C}, 30^{\circ} \mathrm{C}, 40^{\circ} \mathrm{C}$, $50^{\circ} \mathrm{C}, 60^{\circ} \mathrm{C}, 70^{\circ} \mathrm{C}$, and $80^{\circ} \mathrm{C}$ were chosen. Eighty-four tubes were used and placed in water bath (Julabo TW20, Germany). Then the tubes were added to $5 \mathrm{~mL}$ of four chemical solutions: solution A (SA) $0.05 \mathrm{M} \mathrm{NaCl}$; solution B (SB) $0.6 \mathrm{M} \mathrm{NaCl}$; solution C (SC) $1.5 \mathrm{M}$ urea+0.6 M NaCl; solution D (SD) 8.0 $\mathrm{M}$ urea $+0.6 \mathrm{M} \mathrm{NaCl}$, which disrupted some bond types including ionic bonding, hydrogen bonding and hydrophobic interactions. Proteins were partially solubilized in these solutions to measure the existence of ionic bonds (difference between SB and SA), hydrogen bonds (difference between $\mathrm{SC}$ and $\mathrm{SB}$ ) and hydrophobic interactions (difference between SD and SC). In total 28 solutions (three tubes for each solution) were obtained and then homogenized (Ultraturrax $\mathrm{T}_{25}$, IKA, 
Germany) two times for $30 \mathrm{~s}$ at 10,000 rpm. The mixtures were placed at $4^{\circ} \mathrm{C}$ for $1 \mathrm{~h}$ and centrifuged (Beckman Avanti J-E, Beckman Coulter, USA) at 10,000 $\times \mathrm{g}$ for $15 \mathrm{~min}$. the Biuret method were used to measure the protein concentration of the supernatants [17]. The ionic bonding was expressed as the difference in protein concentrations between SA and SB samples. Hydrogen bonding was expressed as the difference in protein concentrations between SC and SB samples. Hydrophobic interaction was expressed as the difference in protein concentrations between SD and SC samples.

\section{Statistical analysis}

The actomyosin was extracted from normal and PSE-like meat at different occasions to conduct three independent replications. All data were presented as mean \pm standard deviation. Statistical Analysis System (SAS 8.2) (SAS Institute Inc., Cary, NC, USA) was used to carry out the statistical analysis of the data. The independent sample $t$ test was used to compare the difference in meat qualities, gel strength, differential scanning calorimetry (DSC) data, chemical groups and molecule forces between normal and PSE-like actomyosin. The data obtained for the particle size, biochemical changes and molecule forces of actomyosin during heating process were submitted to analysis of variance by the general linear model procedures of SAS 8.2. Duncan's multiple range test $(\mathrm{p}<0.05)$ was applied to compare the means of variables among different treatments.

\section{RESULTS AND DISCUSSION}

The characteristics of normal and pale, soft and exudative-like chicken breast meat

The characteristics of normal and PSE-like meat are shown in Table 1. Significant differences were observed $(\mathrm{p}<0.05)$ for $\mathrm{L}^{*}$ and $\mathrm{pH}$ at $3 \mathrm{~h}$ and $24 \mathrm{~h}$ between normal meat and PSE-like meat. The measurement of drip loss clearly indicated that each color group was representative for the two different meat qualities. Therefore, two group chicken breast meat samples were used for this study to further analysis.

Table 1. Characteristics of normal and PSE-like chicken meat

\begin{tabular}{lrr}
\hline \multirow{2}{*}{ Parameter $^{1)}$} & \multicolumn{2}{c}{ Meat color group } \\
\cline { 2 - 3 } & \multicolumn{1}{c}{ Normal } & \multicolumn{1}{c}{ PSE-like } \\
\hline $\mathrm{L}^{*}{ }_{3 \mathrm{~h}}$ & $49.79 \pm 2.24^{\mathrm{b}}$ & $55.11 \pm 2.08^{\mathrm{a}}$ \\
$\mathrm{pH}_{3 \mathrm{~h}}$ & $6.02 \pm 0.06^{\mathrm{a}}$ & $5.85 \pm 0.07^{\mathrm{b}}$ \\
$\mathrm{L}^{*}{ }_{24 \mathrm{~h}}$ & $51.86 \pm 1.42^{\mathrm{b}}$ & $58.63 \pm 2.21^{\mathrm{a}}$ \\
$\mathrm{pH}_{24 \mathrm{~h}}$ & $5.98 \pm 0.07^{\mathrm{a}}$ & $5.63 \pm 0.05^{\mathrm{b}}$ \\
Drip loss (\%) ${ }_{24 \mathrm{~h}}$ & $1.36 \pm 0.51^{\mathrm{b}}$ & $3.59 \pm 1.12^{\mathrm{a}}$ \\
\hline
\end{tabular}

PSE, pale, soft and exudative.

1) $\mathrm{L}^{*}{ }_{\mathrm{h}}$ and $\mathrm{pH}_{3 \mathrm{~h}}$ were determined at $3 \mathrm{~h}$ postmortem; $\mathrm{L}^{*}{ }_{24 \mathrm{~h}}$ and $\mathrm{pH}_{24 \mathrm{~h}}$ were determined at $24 \mathrm{~h}$ postmortem; Drip loss (\%) ${ }_{24 \mathrm{~h}}$ was determined at $24 \mathrm{~h}$ postmortem.

${ }^{a-b}$ Different letters indicate significant differences between the means in the same row $(p<0.05)$.
Sodium dodecyl sulphate-polyacrylamide gel electrophoresis of actomyosin

Figure 1 shows the protein profiles for actomyosin extracted from normal and PSE-like meat by SDS-PAGE. There were similar protein profiles between normal and PSE-like actomyosin. These protein profiles are mainly comprised myosin and actin, and containing other proteins such as troponin, tropomyosin, $\alpha$-actinin and c-protein which are mainly connected with myosin and actin [23]. There were no significant differences ( $p>0.05)$ in the characteristics of actomyosin, suggesting that the associated variation in gel properties between normal and PSE-like meat were attributable to other physico-chemical properties instead of the variation in the protein bands of extracted actomyosin. The results agreed with Chan et al [24], who found that electrophoretic band patterns of myosin and actin from PSE-like and normal turkey meat were not different. However, Barbut et al [6] found the loss of 151-kDa band in the proteins extracted from PSE like meat. The different SDSPAGE results between the present study and Barbut et al [6] may be due to the different samples. The protein samples were extracted from individual broiler breast in the report by Barbut

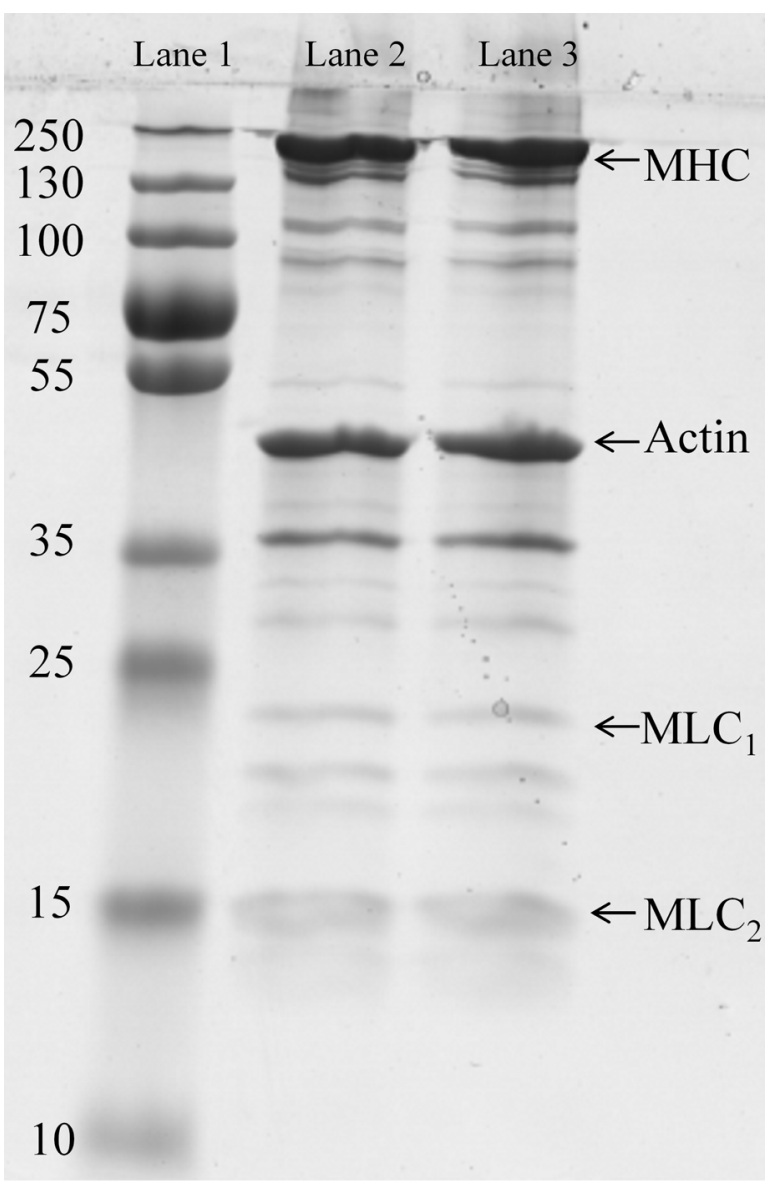

Figure 1. Sodium dodecyl sulphate-polyacrylamide gel electrophoresis of normal and pale, soft and exudative (PSE)-like actomyosin. Lanes 1, standard marker; lanes 2, normal actomyosin; lanes 3, PSE-like actomyosin; MHC, myosin heavy chains; MLC, myosin light chains. 
et al [6] while the mixed broiler meat was used for this study. Eadmusik et al [25] found that the different individual turkey breast meat had different protein profiles identified by SDSPAGE and Western blotting although the protein samples were extracted from the same fast glycolysing group in term of PSE syndrome development.

\section{Particle size distribution}

The changes in particle size distribution of normal and PSElike actomyosin under different $\mathrm{KCl}$ concentrations are shown in Figure 2 and Table 2. In low $\mathrm{KCl}$ concentration condition $(50 \mathrm{mM} \mathrm{KCl})$, the profile of actomyosin in general consisted of two major peaks (one peak range 10 to $100 \mu \mathrm{m}$, another peak range 100 to $1,000 \mu \mathrm{m})$. In high $\mathrm{KCl}$ concentration condition $(0.6 \mathrm{~mol} / \mathrm{L} \mathrm{KCl})$, the particle size distribution profiles of actomyosin became more uniform, occurring a transformation of particle size distribution with a larger number of particles (100 to $1,000 \mu \mathrm{m}$ ). The higher ionic strength increased the charge of actomyosin and affected the electrostatic interactions to cause variable shifting in the particle size distribution $[26,27]$.

There were significant differences in particle size distribution between normal and PSE-like actomyosin $(\mathrm{p}<0.05)$ (Table 2). In low salt concentration, PSE-like actomyosin had lower the values of $\mathrm{D}_{50}, \mathrm{D}_{3,2}$, and $\mathrm{D}_{4,3}$ than those of normal actomyosin. The high ionic strength caused a significant increase in particle size $\left(\mathrm{D}_{50}, \mathrm{D}_{90}, \mathrm{D}_{3,2}\right.$, and $\left.\mathrm{D}_{4,3}\right)$ of both normal and PSElike actomyosin $(\mathrm{p}<0.05)$. Compared with normal actomyosin,
Table 2. Particle size of normal and PSE-like actomyosin under different $\mathrm{KCl}$ concentration conditions

\begin{tabular}{lrrrr}
\hline \multirow{2}{*}{ Samples $^{2)}$} & \multicolumn{4}{c}{ Particle size $^{1)}(\boldsymbol{\mu m})$} \\
\cline { 2 - 5 } & $\mathbf{D}_{50}$ & $\mathbf{D}_{90}$ & $\mathbf{D}_{3,2}$ & $\mathbf{D}_{4,3}$ \\
\hline N & $60.30 \pm 0.40^{\mathrm{c}}$ & $256.00 \pm 7.94^{\mathrm{b}}$ & $38.10 \pm 0.20^{\mathrm{c}}$ & $99.90 \pm 2.02^{\mathrm{b}}$ \\
P & $47.40 \pm 0.40^{\mathrm{d}}$ & $254.00 \pm 5.86^{\mathrm{b}}$ & $29.80 \pm 0.15^{\mathrm{d}}$ & $91.80 \pm 1.51^{\mathrm{c}}$ \\
NS & $171.00 \pm 3.21^{\mathrm{a}}$ & $474.00 \pm 13.05^{\mathrm{a}}$ & $89.30 \pm 1.04^{\mathrm{a}}$ & $218.00 \pm 5.29^{\mathrm{a}}$ \\
PS & $161.00 \pm 3.00^{\mathrm{b}}$ & $481.00 \pm 12.22^{\mathrm{a}}$ & $78.30 \pm 0.95^{\mathrm{b}}$ & $215.00 \pm 5.03^{\mathrm{a}}$ \\
\hline
\end{tabular}

PSE, pale, soft and exudative.

${ }^{1)} D_{50 \%}$, the size of the particle for which $50 \%$ of the sample is below this size; $D_{90 \%}$, the size of the particle for which $90 \%$ of the sample is below this size; $D_{(3,2)}$ r the surface area moment mean diameter, $D_{(3,2)}=\sum n_{i} d_{i}^{3} / \sum n_{i} d_{i}^{2}$, where ni is the number of particles with diameter di and was calculated from the size distribution; $D_{(4,3)}$, the volume moment mean diameter, $D_{(4,3)}=\sum n_{i} d_{i}^{4} / \sum n_{i} d_{i}^{3}$, where $n_{i}$ is the number of particles with diameter $d_{i}$ and was calculated from the size distribution.

${ }^{2)} \mathrm{N}$ and $\mathrm{P}$, normal and PSE-like at low $\mathrm{KCl}$ concentration condition (50 mM KCl); NS and PS, normal and PSE-like actomyosin at high $\mathrm{KCl}$ concentration condition (0.6 M KCl).

${ }^{a-d}$ Different letters indicate significant differences among the means in the same column $(p<0.05)$.

PSE-like actomyosin had lower values of $\mathrm{D}_{50}$ and $\mathrm{D}_{3,2}(\mathrm{p}<0.05)$. PSE-like actomyosin had lower particle size than that of normal actomyosin, which was attributed to different glycolytic development between PSE and normal meat. Actomyosin is the main existing form of myosin and actin filaments in the rigor state [28]. PSE-like meat had both faster acidification process and extent, thus resulting in a more tightly binding of myosin with actin [12,28]. It is proposed that the particle size variation may induce the difference in gel forming ability

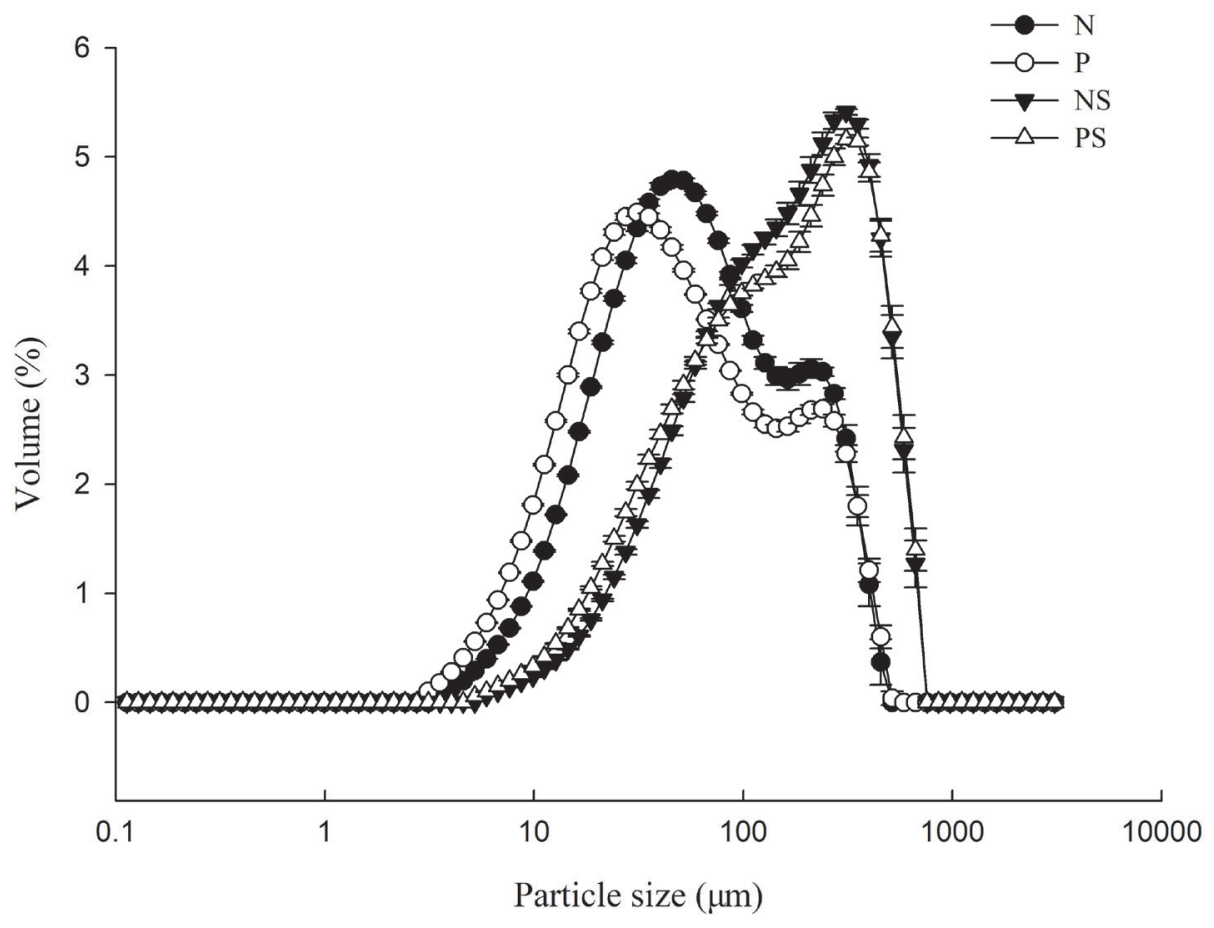

Figure 2. Particle size distribution of normal and pale, soft and exudative (PSE)-like actomyosin under different $\mathrm{KCl}$ concentration conditions. N and P, normal and PSE-like actomyosin at low KCl concentration condition ( $50 \mathrm{mM} \mathrm{KCl);} \mathrm{NS} \mathrm{and} \mathrm{PS,} \mathrm{normal} \mathrm{and} \mathrm{PSE-like} \mathrm{actomyosin} \mathrm{at} \mathrm{high} \mathrm{KCl}$ concentration condition (0.6 M KCI). 
between normal and PSE-like meat.

Gel strength, water-holding capacity, protein loss and differential scanning calorimetry analysis

As shown in Table 3, there were significant difference in gel strength, WHC and protein loss between normal and PSElike actomyosin $(p<0.05)$. The gel strength and WHC of PSElike actomyosin were lower than those of normal actomyosin at the same protein concentration. The results indicated that the native proteins from PSE-like meat have less functionalities including the lower thermal gelling ability and less effectively trapping water. Protein loss in the expelled liquid after cooking and centrifugation for the PSE-like actomyosin were significantly higher than that for normal actomyosin $(\mathrm{p}<0.05)$, suggesting that less protein-protein interaction occurs in the PSE-like meat during heating process. Camou and Sebranek [10] also found that there were similar observations in salt soluble proteins of PSE pork. These results indicated that the associated functional variation in PSE-like meat could not be explained solely by the variation in the salt soluble protein extraction and $\mathrm{pH}$ of PSE-like meat when used in common further processing. Consequently, changes in characteristics of the intrinsic muscle proteins were possibly an important factor in causing weaker thermal gelation ability and WHC of PSE-like meat. Table 3 also shows the thermal denaturation temperature and enthalpy in normal and PSE-like actomyosin. Compared with normal actomyosin, there were significant reduction in $\mathrm{T}_{0}$ and $\mathrm{T}_{\mathrm{d}}$ from PSE-like actomyosin $(\mathrm{p}<0.05)$. This indicated that actomyosin extracted from PSE-like meat were destabilized and became more susceptible to thermal denaturation. However, no significant difference was observed in $\mathrm{T}_{\mathrm{e}}$ and $\Delta \mathrm{H}$ between normal and PSE-like actomyosin $(\mathrm{p}>0.05)$.

Previous studies reported thermal denaturation of muscle

Table 3. Gel strength, WHC, protein loss, thermal denaturation temperature and enthalpy of normal and PSE-like actomyosin

\begin{tabular}{lcc}
\hline \multirow{2}{*}{ Parameter } & \multicolumn{2}{c}{ Actomyosin } \\
\cline { 2 - 3 } & \multicolumn{1}{c}{ Normal } & PSE-like \\
\hline Gel strength $(\mathrm{g})$ & $32.60 \pm 3.29^{\mathrm{a}}$ & $26.41 \pm 1.98^{\mathrm{b}}$ \\
WHC $(\%)$ & $31.95 \pm 3.06^{\mathrm{b}}$ & $37.04 \pm 4.22^{\mathrm{a}}$ \\
Proteins loss $(\mathrm{mg} / \mathrm{mL})$ & $2.74 \pm 0.18^{\mathrm{b}}$ & $3.15 \pm 0.26^{\mathrm{a}}$ \\
DSC & & \\
$\mathrm{T}_{0}\left({ }^{\circ} \mathrm{C}\right)$ & $53.29 \pm 0.65^{\mathrm{a}}$ & $50.01 \pm 0.53^{\mathrm{b}}$ \\
$\mathrm{T}_{d}\left({ }^{\circ} \mathrm{C}\right)$ & $55.95 \pm 0.46^{\mathrm{b}}$ & $53.58 \pm 0.25^{\mathrm{a}}$ \\
$\mathrm{T}_{e}\left({ }^{\circ} \mathrm{C}\right)$ & $57.93 \pm 1.09^{\mathrm{a}}$ & $57.45 \pm 1.07^{\mathrm{a}}$ \\
$\Delta H(\mathrm{~J} / \mathrm{g})$ & $0.021 \pm 0.002^{\mathrm{a}}$ & $0.020 \pm 0.001^{\mathrm{a}}$ \\
\hline
\end{tabular}

WHC, water-holding capacity; PSE, pale, soft and exudative; DSC, differential scanning calorimetry; $T_{0}$, the onset temperature of thermal denaturation for actomyosin; $T_{d}$, the maximum temperature of thermal denaturation for actomyosin; $T_{e}$ the end temperature of thermal denaturation for actomyosin; $\Delta H$, the enthalpy of thermal denaturation for actomyosin.

${ }^{a-b}$ Different letters indicate significant differences between the means in the same row $(p<0.05)$. proteins extracted from different meat qualities $[29,30]$. Liu et al [30] reported that there were three or five endothermic transition peaks for chicken myofibrillar proteins after the separation and purifying. Park and Lanier [31] found that there were three endothermic transition peaks for tilapia proteins after purification, mainly corresponding to myofibril $\left(47.8^{\circ} \mathrm{C}\right)$, myosin $\left(57.7^{\circ} \mathrm{C}\right)$, and actin $\left(68^{\circ} \mathrm{C}\right)$. These transition temperatures indicated proteins conformational changes during thermal denaturation, one of which was transformed from $\alpha$-helix into random coil for promoting the thermal induced gelation of myofibrillar proteins. In addition, the range of transition temperature for myosin and actomyosin were very wide for different studies [30,31]. The denatured temperature range for the purified myosin and actin were from $39.6^{\circ} \mathrm{C}$ to $65.1^{\circ} \mathrm{C}$ and $43.5^{\circ} \mathrm{C}$ to $71.1^{\circ} \mathrm{C}$, respectively. It was suggested that the extracted protein denaturation temperature probably have different values, which may be due to specific $\mathrm{pH}$ and ionic conditions, use of different proteins extraction methods or the sample concentrations [32,33]. Wright et al [33] reported that no endothermic transition peaks were observed when the concentration of protein was adjusted to higher than $20 \mathrm{mg} / \mathrm{mL}$, because proteins formed a gel network during heating. The present study found one endothermic transition peak from $50^{\circ} \mathrm{C}$ to $55^{\circ} \mathrm{C}$, indicating an increase binding of actomyosin. Actin could interact with myosin during thermal treatment, thus resulted in the changes of gel elasticity [12]. PSE-like actomyosin exhibited lower thermal stability of actomyosin suggesting there is a variation in the denaturation and aggregation of actomyosin to induce the differences in the gel properties between normal and PSE-like actomyosin.

The lower gel strength and WHC of PSE-like actomyosin probably resulted from the faster acidification rate and higher acidification extent in term of PSE-like syndrome development [12]. Rapid glycolysis or lower $\mathrm{pH}$ in PSE-like meat induced changes in the myofibrillar structures, promoted higher protein denaturation and degradation of proteins $[34,35]$, which may lower the transition temperature and limit the gel-forming ability of actomyosin, thus have a negative effect on the gel strength and WHC. The higher rate and extent of protein degradation in PSE-like meat also resulted in the smaller particle size of PSE-like actomyosin [36], which may lead to the differences (low gel strength, low WHC, low heat stability) between actomyosins extracted from normal and PSE like meat.

\section{Storage modulus and loss modulus}

Figure 3 shows changes in $\mathrm{G}^{\prime}$ and $\mathrm{G}^{\prime \prime}$ of normal and PSE-like actomyosin during heat-induced gelation process. The $\mathrm{G}^{\prime}$ of normal actomyosin increased slowly from heating to approximately $45^{\circ} \mathrm{C}$ in the beginning, then increased quickly to a maximum at $49^{\circ} \mathrm{C}$ with exhibiting a peak (Figure $3 \mathrm{~A}$ ). It then decreased sharply to a minimum at $56^{\circ} \mathrm{C}$. On further heating to $80^{\circ} \mathrm{C}$, the $\mathrm{G}^{\prime}$ increased steadily. The early increase in $\mathrm{G}^{\prime}$ in- 

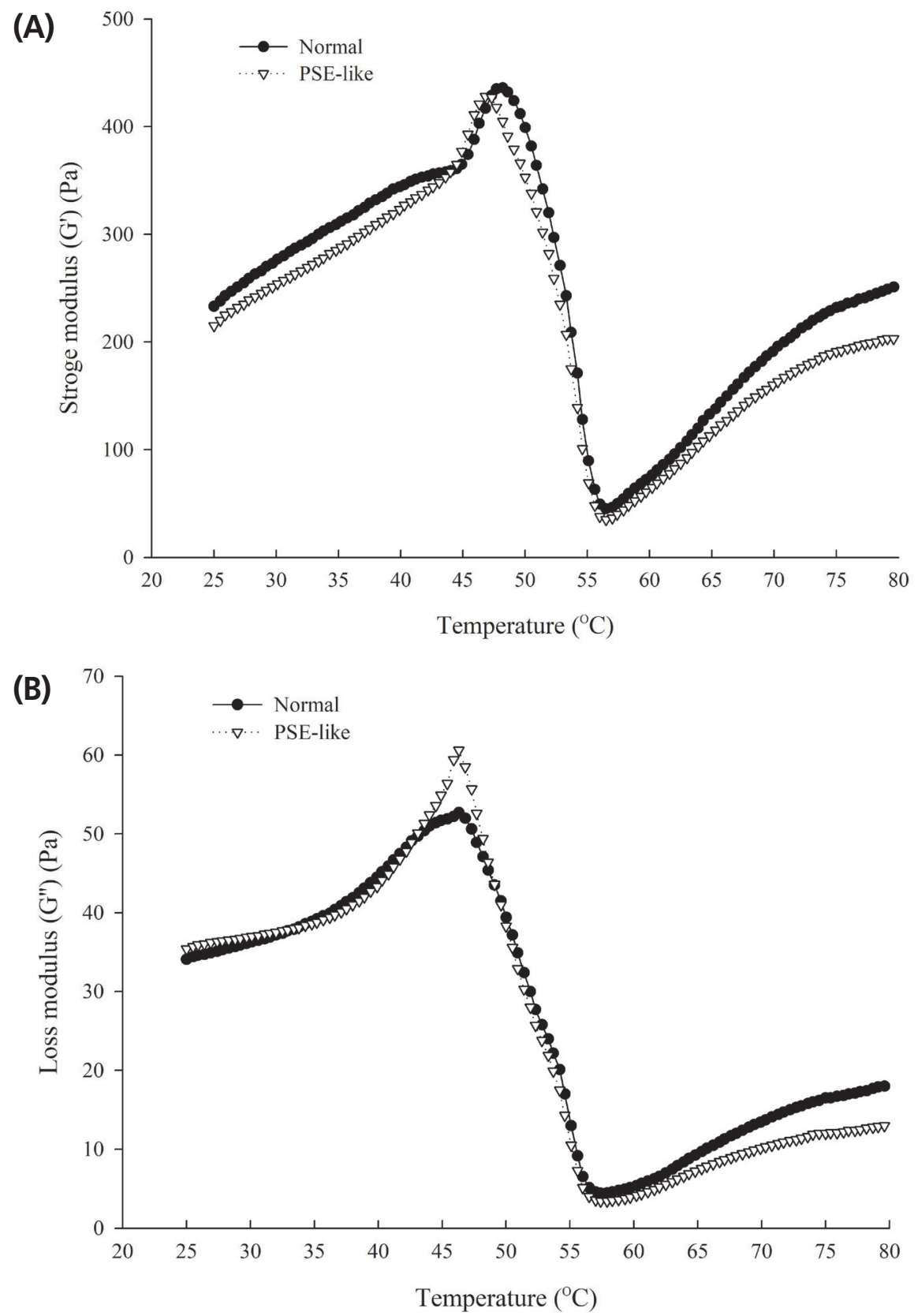

Figure 3. Changes in dynamic storage modulus ( $\left.G^{\prime}\right)(A)$ and loss modulus ( $\left.G^{\prime \prime}\right)(B)$ during heating from $25^{\circ} \mathrm{C}$ to $80^{\circ} \mathrm{C}$ for normal and pale, soft and exudative (PSE)-like actomyosin.

dicated that the preliminary elastic protein network structure, which was mainly due to the unfolding and denaturation of myosin heads [37]. The rapid increase of $\mathrm{G}^{\prime}$ was closely related to the unfolding and cross-linking of myosin tails [37]. Then, denaturation of the myosin light chain induced $\mathrm{G}^{\prime}$ to decease sharply and increased the mobility of muscle proteins [38]. On subsequent heating, the increase of $\mathrm{G}^{\prime}$ was attributed to an increase in the amounts of actomyosin cross-links between protein aggregates/strands [39]. The $\mathrm{G}^{\prime}$ of PSE-like actomyosin was lower than that of normal actomyosin at first from heating to approximately $44^{\circ} \mathrm{C}$, then increased sharply up to maximum at $47^{\circ} \mathrm{C}$. It was obvious that a peak earlier appeared for PSElike actomyosin (Figure 3A). The different change in $\mathrm{G}^{\prime}$ in PSElike actomyosin may be due to formation of more protein interactions and aggregates at lower temperature. Subsequently, the $\mathrm{G}^{\prime}$ of PSE-like actomyosin increased relatively slow on further heating and was lower than that of normal actomyosin, indicating heat-induced PSE-like actomyosin gel was less rigid and elastic. These corresponded to the results of the gelation strength of actomyosin. Wang et al [8] reported that the $\mathrm{G}^{\prime}$ of actomyosin extracted from normal and PSE pork have different rheological transitions. The dynamic rheological behavior 
reflected the different changes in biochemical properties of PSE-like native protein during heating, which inferred that it is an important factor affecting the gelation properties of PSE-like chicken meat in addition to the different extents of protein solubility and their $\mathrm{pH}$ values.

Figure 3B shows the changes of $G^{\prime \prime}$ for normal and PSE-like actomyosin during heating process. The first peak of both normal and PSE-like actomyosin appeared at $46^{\circ} \mathrm{C}$, then the $\mathrm{G}^{\prime \prime}$ decreased rapidly to a minimum at $57^{\circ} \mathrm{C}$. Then the changes in $\mathrm{G}^{\prime \prime}$ for both normal and PSE-like actomyosin were like those observed for the $\mathrm{G}^{\prime}$. The $\mathrm{G}^{\prime \prime}$ value at the end heating points indicated that PSE-like actomyosin reduced the viscosity compared to normal actomyosin.

\section{Turbidity, reactive sulfhydryl and surface} hydrophobicity of actomyosin

Figure 4 shows changes in turbidity, reactive sulfhydryl and surface hydrophobicity of normal and PSE-like actomyosin

(A)

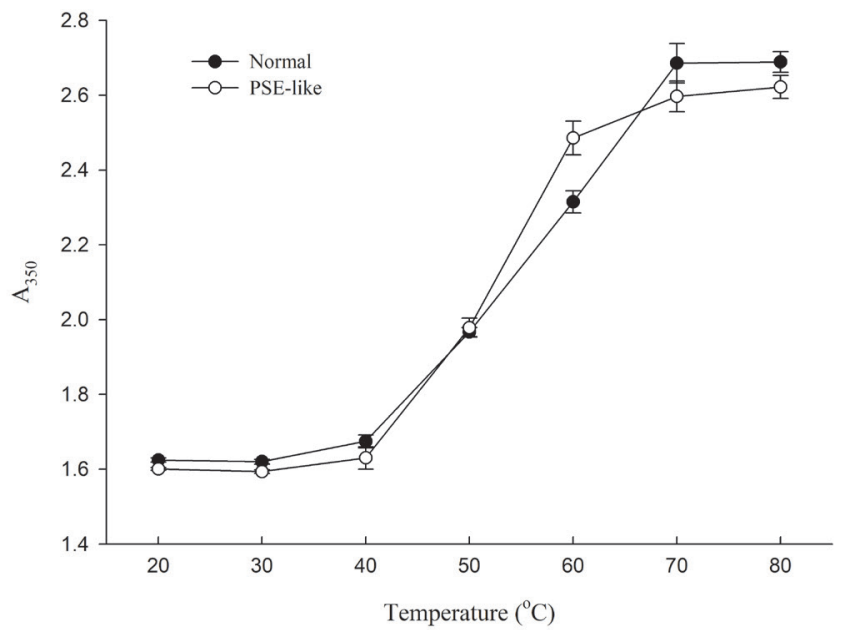

(C)

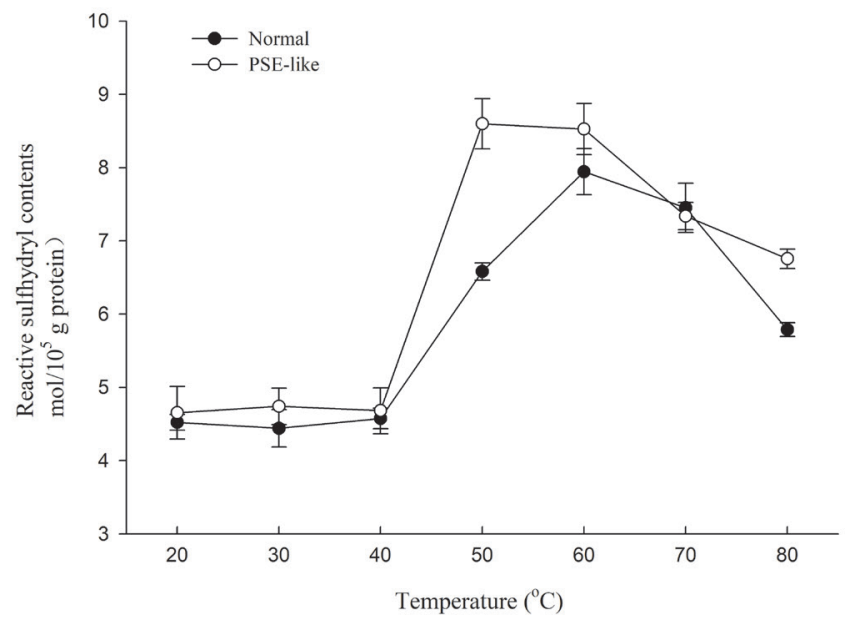

when temperature rose from $20^{\circ} \mathrm{C}$ to $80^{\circ} \mathrm{C}$. As shown in Figure $4 \mathrm{~A}$ and $4 \mathrm{~B}$, both normal and PSE-like actomyosin became more turbid as temperature rose, suggesting protein aggregates were formed and increased. Turbidity was a good indicator of the extent of protein aggregation [40]. The turbidity of normal and PSE-like actomyosin slightly increased during heating from $20^{\circ} \mathrm{C}$ to $40^{\circ} \mathrm{C}$. The turbidity values did not differ significantly during this temperature range. The turbidity was increased significantly from $40^{\circ} \mathrm{C}$ to $60^{\circ} \mathrm{C}(\mathrm{p}<0.05)$. The rate of turbidity for PSE-like actomyosin was higher than that for normal actomyosin during heating from $40^{\circ} \mathrm{C}$ to $60^{\circ} \mathrm{C}$. There was a significant difference at $60^{\circ} \mathrm{C}$ in the turbidity values $(\mathrm{p}<$ 0.05 ) between normal and PSE-like actomyosin (Figure 4A, $4 \mathrm{~B}$ ), indicating the denaturation and aggregation of PSE-like actomyosin were more intense during this temperature range. On further heating from $60^{\circ} \mathrm{C}$ to $80^{\circ} \mathrm{C}$, the turbidity for normal and PSE-like actomyosin continued to go up (Figure 4A; $4 \mathrm{~B})$. There were significant differences in the turbidity between

(B)

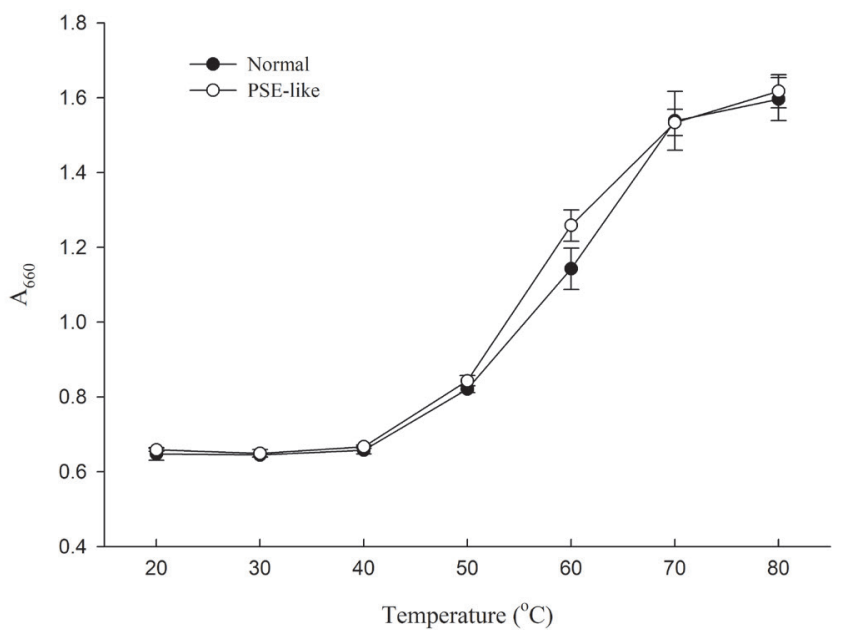

(D)

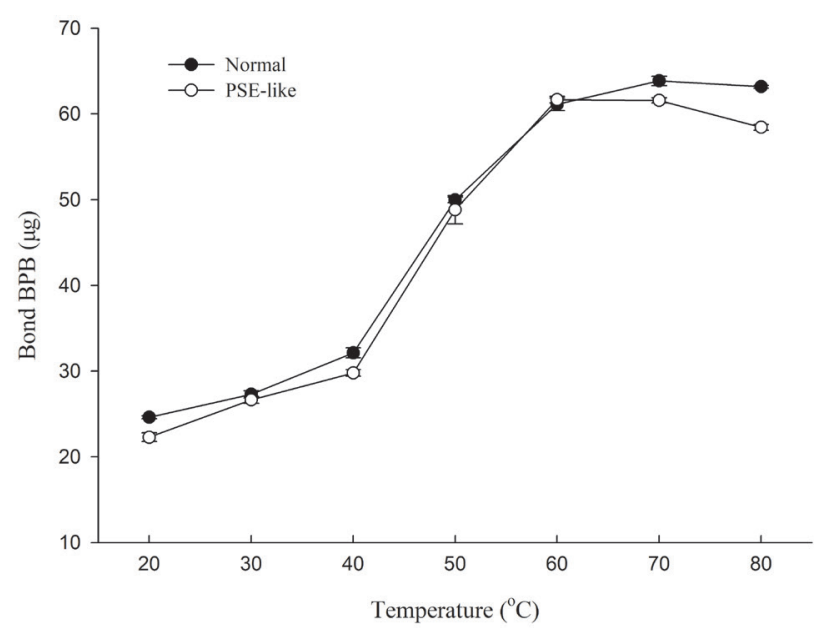

Figure 4. Changes in turbidity measured at $350 \mathrm{~nm}(\mathrm{~A})$ and $660 \mathrm{~nm}$ (B), reactive sulfhydryl (C) and surface hydrophobicity (D) of normal and pale, soft and exudative (PSE)-like actomyosin during heating. 
PSE-like actomyosin normal actomyosin $(\mathrm{p}<0.05)$ in the range $70^{\circ} \mathrm{C}$ to $80^{\circ} \mathrm{C}$ (Figure $4 \mathrm{~A}$ ). This indicated the protein aggregates of PSE-like actomyosin were smaller than those of normal actomyosin. The protein aggregates or large particles were formed by heavy meromyosin and light meromyosin via changing their conformations [37]. Chan and Gill [41] reported that the differences in turbidity were most probably attributed to the variation in the size and/or rate of protein aggregation. These results suggested the varying size and rate of protein aggregation may induce the difference in the gel strength between normal and PSE-like actomyosin.

As shown in Figure 4C, the reactive sulfhydryl of normal and PSE-like actomyosin did not differ significantly during heating from $20^{\circ} \mathrm{C}$ to $40^{\circ} \mathrm{C}$. The reactive sulfhydryl values increased significantly from $40^{\circ} \mathrm{C}$ to $60^{\circ} \mathrm{C}(\mathrm{p}<0.05)$, indicating actomyosin was unfolded to form inter-intra-molecular interactions that could induce protein aggregation [9]. The reactive sulfhydryl value was higher in the PSE-like actomyosin compared to normal actomyosin, suggesting PSE-like actomyosin exhibited a rapid unfolding rate and exposed the buried sulfhydryl groups to its surface $[11,12]$. On further heating from $60^{\circ} \mathrm{C}$ to $80^{\circ} \mathrm{C}$, the reactive sulfhydryl value was significantly decreased $(\mathrm{p}<0.05)$, suggesting the formation of disulfide linkage. PSE-like actomyosin had higher reactive sulfhydryl value than normal actomyosin $(\mathrm{p}<0.05)$ at $80^{\circ} \mathrm{C}$. Compared to normal actomyosin, PSE-like actomyosin began to unfold rapidly at $40^{\circ} \mathrm{C}$ and had a higher temporal rise of reactive sulfhydryl while the decrease of reactive sulfhydryl converted less effectively to disulfide bond on further heating. Lanier [42] reported that the exposed reactive sulfhydryl groups which tend to form the formation of disulfide linkages, played an important role in the gel properties. These differences in reactive sulfhydryl contents confirmed that PSE-like actomyosin had less protein interactions resulting in the increased protein loss and decreased gel strength than normal actomyosin.

As shown in Figure 4D, the surface hydrophobicity of normal and PSE-like actomyosin slightly increased during heating from $20^{\circ} \mathrm{C}$ to $40^{\circ} \mathrm{C}$. The surface hydrophobicity of PSE-like actomyosin was significantly lower $(\mathrm{p}<0.05)$ than that of normal actomyosin. Then a significant increase of surface hydrophobicity occurred for both normal and PSE-like actomyosin as temperature rose from $40^{\circ} \mathrm{C}$ to $60^{\circ} \mathrm{C}(\mathrm{p}<0.05)$. This result indicated the changes in conformation of actomyosin including exposing hydrophobic aromatic amino acid residues to protein surface, which induced the formation of hydrophobic interaction to participate in the gelation process [43,44]. There was no significant difference between the surface hydrophobicity of normal and PSE-like actomyosin at $50^{\circ} \mathrm{C}$ and $60^{\circ} \mathrm{C}$ ( $>0.05$ ), suggesting PSE-like actomyosin exhibited a rapid unfolding rate and exposed the buried hydrophobic aromatic amino acid residues to its surface during heating from $20^{\circ} \mathrm{C}$ to $60^{\circ} \mathrm{C}$ [45]. On subsequent heating to $80^{\circ} \mathrm{C}$, the surface hy- drophobicity of PSE-like actomyosin was significantly lower $(p<0.05)$ than that of normal actomyosin. Sankar and Ramachandran [46] reported that the hydrophobic groups becoming more exposed contributed to the formation of insoluble, turbid aggregates. These results indicated that the difference in the hydrophobic groups could explain the different gelation properties of actomyosin.

\section{Molecular forces}

Different molecular forces of protein-protein interactions during heating process contributed to form and maintain the gelation structures, which included ionic bonds, hydrogen bonds and hydrophobic interactions [14]. Thus, changes in these molecular forces involved in the gelling formation influenced the gel properties of muscle proteins. Different chemical solutions (SA, SB, SC, and SD as aforementioned in section Methods) were chosen to disrupt some types of intermolecular bonds to further understand the variation in the gel formation of normal and PSE-like actomyosin. As shown in Figure 5, normal and PSE-like actomyosin showed similar patterns of molecular forces during heating, as has also been shown previously [47]. The protein solubility as expressed the individual molecular interaction was affected significantly by heating $(\mathrm{p}<0.05)$. There was a significant decrease $(\mathrm{p}<0.05)$ in the ionic and hydrogen bonds as the temperature increased, indicating that the ionic and hydrogen bonds were broken. The ionic bond of PSE-like actomyosin was slightly lower ( $>0.05)$ than that of normal actomyosin at $20^{\circ} \mathrm{C}$. When heating to $40^{\circ} \mathrm{C}$, the ionic bond of PSE-like actomyosin was significantly lower $(p<0.05)$ than that of normal actomyosin. On further heating from $50^{\circ} \mathrm{C}$ to $80^{\circ} \mathrm{C}$, the ionic bond of PSE-like actomyosin was significantly higher $(\mathrm{p}<0.05)$ than that of normal actomyosin, while the hydrogen bond of PSE actomyosin was lower significantly than that of normal actomyosin $(\mathrm{p}<0.05)$ on heating from $60^{\circ} \mathrm{C}$ to $80^{\circ} \mathrm{C}$. Hydrophobic interaction started to increase at $20^{\circ} \mathrm{C}$ and reached a maximum at $50^{\circ} \mathrm{C}$, then gradually fell to a steady state on further heating. Heating induced the unfolding of the peptide chains in native proteins and increased the exposure of some buried hydrophobic groups to extend on the surfaces [15], which was related to changes in the conformation of myosin tails. Compared to the ionic and hydrogen bonds, the value of protein solubility as expressed by the hydrophobic action was the highest $(\mathrm{p}<0.05)$ at the end of heating treatment, which indicated that the main molecular force was hydrophobic interaction contributing to the gelation properties of proteins. However, the hydrophobic interaction of PSElike actomyosin was not significantly lower than that of normal actomyosin ( $p>0.05$ ) on heating from $60^{\circ} \mathrm{C}$ to $80^{\circ} \mathrm{C}$. The significant differences in the ionic and hydrogen bonds were observed between normal and PSE-like actomyosin at the end of heating treatment $(p<0.05)$, which may induce the difference in gelation properties between normal and PSE-like 
(A)

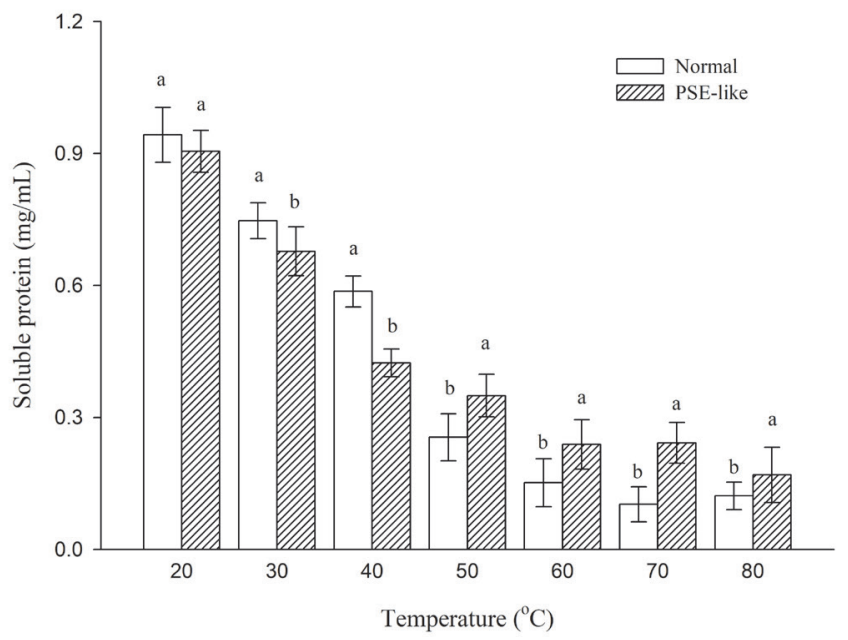

(C)

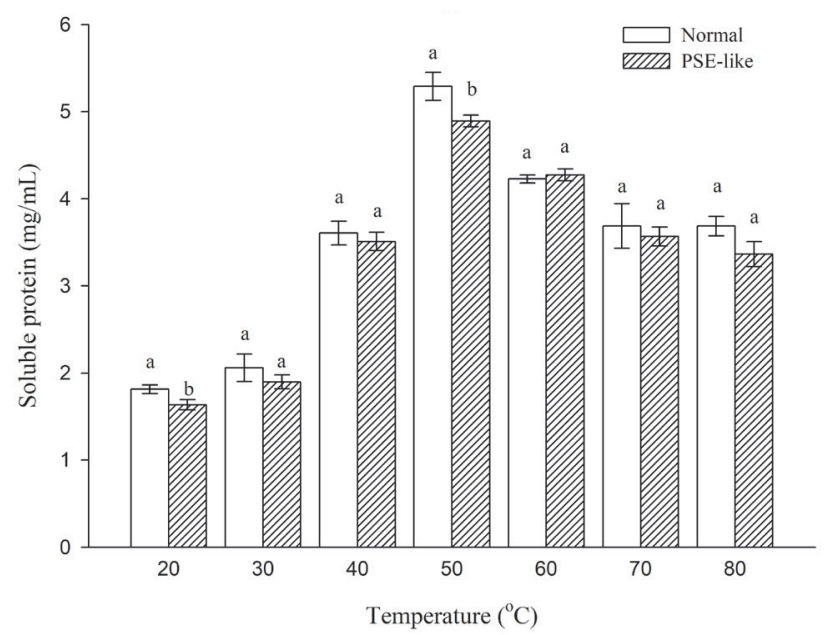

(B)

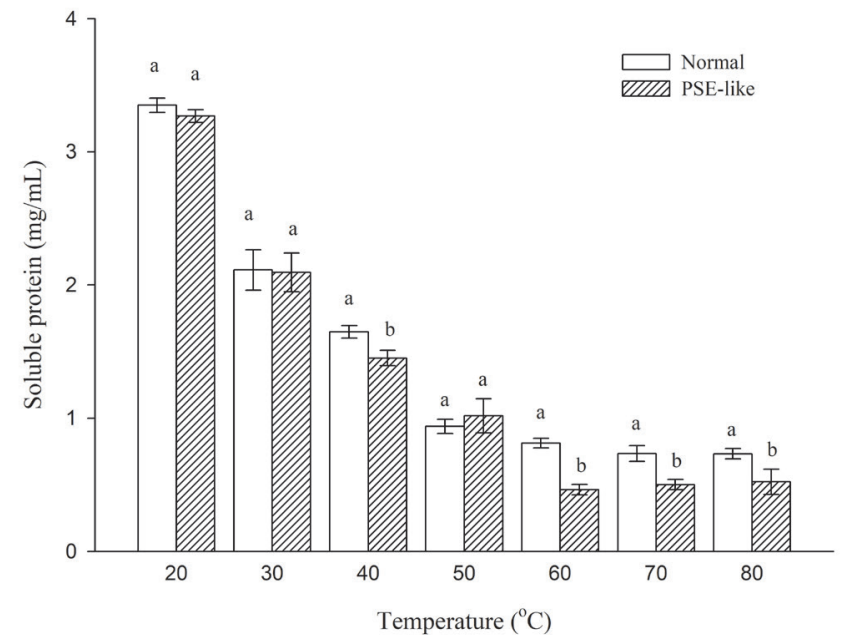

Figure 5. Changes in ionic bond (A), hydrogen bond (B), and hydrophobic interaction (C) of normal and pale, soft and exudative (PSE)-like actomyosin during heating. ${ }^{\text {a-b }}$ Different letters indicate significant differences among the means at the same temperature.

actomyosin. The gel network formation of muscle proteins was constructed and maintained by these molecular interactions of protein-protein and protein-water in the gel system [48]. The contribution of various chemical forces to maintain the gel network varies in different protein systems and conditions. Liu et al [13] reported that ionic bonds and hydrogen bonds contributed significantly to stabilize protein conformations, increase protein- water interactions and gel formation of muscle proteins.

\section{CONCLUSION}

The experiments performed in this study investigated the thermal gelling properties and molecular forces of actomyosin extracted from normal and PSE-like chicken breast meat. PSElike actomyosin had lower gel strength, WHC and less protein content involved in the thermal gelling forming. SDS-PAGE showed similar patterns of actomyosin extracted from PSE-like and normal meat. However, PSE-like actomyosin had different viscoelastic patterns of thermal gelation from normal actomyosin and reduced the $\mathrm{G}^{\prime}$ and $\mathrm{G}^{\prime \prime}$. The transition temperature of $\mathrm{G}^{\prime}$, particle size and the thermal transition temperature $\left(\mathrm{T}_{\mathrm{d}}\right)$ for PSE-like actomyosin were lowered than those for normal actomyosin. Moreover, the rate of increase was higher for the turbidity, sulfhydryl group contents and hydrophobicity of PSE-like actomyosin in the range of $40^{\circ} \mathrm{C}$ to $60^{\circ} \mathrm{C}$, indicating that protein aggregation was more intense. While the transition from reactive sulfhydryl group into a disulfide bond of PSE-like actomyosin was less than those normal actomyosin after heating treatment. Molecular forces showed the different changes in ionic and hydrogen bonds between PSE-like and normal actomyosin at the end of heating treatment, indicating these differences in the formation of chemical groups and intermolecular bonds possibly affected protein-protein in- 
teraction and contributed to diverse gelation properties between PSE-like and normal actomyosin. This study clearly demonstrated the loss in native protein functionality caused the impaired functional properties of PSE-like chicken breast meat besides other factors such as $\mathrm{pH}$ and lower protein extraction during meat traditional processing.

\section{CONFLICT OF INTEREST}

We certify that there is no conflict of interest with any financial organization regarding the material discussed in the manuscript.

\section{ACKNOWLEDGMENTS}

This work was funded by the National Natural Science Foundation of China (NSFC, Grant No. 31601492), the National Key Research and Development Program of China (Grant No. 2018YFD0401200), Key Scientific Research Project of Henan Institution of Higher Education (16A550006), Research Fund Project of Zhengzhou University of light industry (2015BSJJ038) and the Foundation for Young Key Teachers of Zhengzhou University of Light Industry (201711).

\section{REFERENCES}

1. Jiang N, Wang P, Xing T, et al. An evaluation of the effect of water-misting sprays with forced ventilation on the occurrence of pale, soft, and exudative meat in transported broilers during summer: Impact of the thermal microclimate. J Anim Sci 2016; 94:2218-27.

2. Zhao X, Xing T, Chen X, et al. Yield, thermal denaturation, and microstructure of proteins isolated from pale, soft, exudative chicken breast meat by using isoelectric solubilization/ precipitation. Process Biochem 2017;58:167-73.

3. Petracci M, Bianchi M, Mudalal S, et al. Functional ingredients for poultry meat products. Trends Food Sci Technol 2013;33: 27-39.

4. Chen $\mathrm{H}$, Wang HH, Qi J, et al. Chicken breast quality-normal, pale, soft and exudative (PSE) and woody-influences the functional properties of meat batters. Int J Food Sci Technol 2018; 53:654-64.

5. Li K, Chen L, Zhao YY, et al. A comparative study of chemical composition, color, and thermal gelling properties of normal and PSE-like chicken breast meat. CyTA-J Food 2015;13:213-9.

6. Barbut S, Zhang L, Marcone M. Effects of pale, normal, and dark chicken breast meat on microstructure, extractable proteins, and cooking of marinated fillets. Poult Sci 2005;84:797802.

7. Sun XD, Holley RA. Factors influencing gel formation by myofibrillar proteins in muscle foods. Compr Rev Food Sci Food Saf 2011;10:33-51.
8. Wang H, Pato MD, Shand PJ. Biochemical properties of natural actomyosin extracted from normal and pale, soft, and exudative pork loin after frozen storage. J Food Sci 2005;70:C313-20.

9. Liu R, Zhao S, Yang H, et al. Comparative study on the stability of fish actomyosin and pork actomyosin. Meat Sci 2011;88: 234-40.

10. Camou JP, Sebranek JG. Gelation characteristics of muscle proteins from pale, soft, exudative (PSE) pork. Meat Sci 1991;30: 207-20.

11. Wang H, Pato M, Pietrasik Z, Shand P. Biochemical and physicochemical properties of thermally treated natural actomyosin extracted from normal and PSE pork Longissimus muscle. Food Chem 2009;113:21-7.

12. Li K, Zhao YY, Kang ZL, et al. Reduced functionality of PSElike chicken breast meat batter resulting from alterations in protein conformation. Poult Sci 2015;94:111-22.

13. Liu R, Zhao SM, Xie BJ, et al. Contribution of protein conformation and intermolecular bonds to fish and pork gelation properties. Food Hydrocoll 2011;25:898-906.

14. Zhao X, Xing T, Chen X, et al. Changes of molecular forces during thermo-gelling of protein isolated from PSE-like chicken breast by various isoelectric solubilization/precipitation extraction strategies. Food Bioproc Tech 2017;10:1240-7.

15. Ni N, Wang Z, He F, et al. Gel properties and molecular forces of lamb myofibrillar protein during heat induction at different pH values. Process Biochem 2014;49:631-6.

16. Ogawa M, Nakamura S, Horimoto Y, et al. Raman spectroscopic study of changes in fish actomyosin during setting. J Agric Food Chem 1999;47:3309-18.

17. Gornall AG, Bardawill CJ, David MM. Determination of serum proteins by means of the biuret reaction. J Biol Chem 1949; 177:751-66.

18. Laemmli UK. Cleavage of structural proteins during the assembly of the head of bacteriophage T4. Nature 1970;227:680-5.

19. Li K, Kang ZL, Zhao YY, et al. Use of high-intensity ultrasound to improve functional properties of batter suspensions prepared from PSE-like chicken breast meat. Food Bioproc Tech 2014; 7:3466-77.

20. Chen H, Han M. Raman spectroscopic study of the effects of microbial transglutaminase on heat-induced gelation of pork myofibrillar proteins and its relationship with textural characteristics. Food Res Int 2011;44:1514-20.

21. Kocher P, Foegeding E. Microcentrifuge-based method for measuring water holding of protein gels. J Food Sci 1993;58:10406.

22. Ellman GL. Tissue sulfhydryl groups. Arch Biochem Biophys 1959;82:70-7.

23. Acton JC, Dick RL. Thermal transitions of natural actomyosin from poultry breast and thigh tissues. Poult Sci 1986;65:20515.

24. Chan JTY, Omana DA, Betti M. Functional and rheological properties of proteins in frozen turkey breast meat with different 
ultimate pH. Poult Sci 2011;90:1112-23.

25. Eadmusik S, Molette C, Fernandez X, et al. Are one early muscle $\mathrm{pH}$ and one early temperature measurement sufficient to detect PSE breast meat in turkeys? Br Poult Sci 2011;52:177-88.

26. Pighin DG, Sancho AM, Gonzalez CB. Effect of salt addition on the thermal behavior of proteins of bovine meat from Argentina. Meat Sci 2008;79:549-56.

27. Feng M, Pan L, Yang X, et al. Thermal gelling properties and mechanism of porcine myofibrillar protein containing flaxseed gum at different $\mathrm{NaCl}$ concentrations. LWT-Food Sci Technol 2018;87:361-7.

28. Liu J, Schwartzkopf M, Arner A. Rigor bonds cause reduced sarcomeric volume in skinned porcine skeletal muscle under PSE-like conditions. Meat Sci 2018;139:91-6.

29. Lesiów T, Xiong YL. A simple, reliable and reproductive method to obtain experimental pale, soft and exudative (PSE) pork. Meat Sci 2013;93:489-94.

30. Liu MN, Foegeding EA, Wang SF, et al. Denaturation and aggregation of chicken myosin isoforms. J Agric Food Chem 1996; 44:1435-40.

31. Park JW, Lanier TC. Scanning calorimetric behavior of tilapia myosin and actin due to processing of muscle and protein purification. J Food Sci 1989;54:49-51.

32. Ishioroshi M, Jima KS, Yasui T. Heat-induced gelation of myosin: factors of $\mathrm{pH}$ and salt concentrations. J Food Sci 1979;44:12804.

33. Wright DJ, Wilding P. Differential scanning calorimetric study of muscle and its proteins: myosin and its subfragments. J Sci Food Agric 1984;35:357-72.

34. Wilhelm AE, Maganhini MB, Hernández-Blazquez FJ, et al. Protease activity and the ultrastructure of broiler chicken PSE (pale, soft, exudative) meat. Food Chem 2010;119:1201-4.

35. D'Alessandro A, Zolla L. Meat science: From proteomics to integrated omics towards system biology. J Proteomics 2013; 78:558-77.

36. Chen L, Li C, Ullah N, et al. Different physicochemical, structural and digestibility characteristics of myofibrillar protein from PSE and normal pork before and after oxidation. Meat Sci 2016;121:228-37.
37. Xiong YL, Bacnchard SP. Myofibrillar protein gelation: viscoelastic changes related to heating procedures. J Food Sci 1994; 59:734-8.

38. Egelandsdal B, Fretheim K, Samejima K. Dynamic rheological measurements on heat-induced myosin gels: effect of ionic strength, protein concentration and addition of adenosine triphosphate or pyrophosphate. J Sci Food Agric 1986;37:91526.

39. Zhao YY, Wang P, Zou YF, et al. Effect of pre-emulsification of plant lipid treated by pulsed ultrasound on the functional properties of chicken breast myofibrillar protein composite gel. Food Res Int 2014;58:98-104.

40. Xu Y, Xia W, Jiang Q. Aggregation and structural changes of silver carp actomyosin as affected by mild acidification with d-gluconic acid $\delta$-lactone. Food Chem 2012;134:1005-10.

41. Chan JK, Gill TA. Thermal aggregation of mixed fish myosins. J Agric Food Chem 1994;42:2649-55.

42. Lanier TC, Carvajal P, Yongsawatdigul J. Surimi gelation chemistry. In: Park JW, editor. Surimi and surimi seafood. Boca Raton, FL, USA: CRC press; 2013, p. 101-39.

43. Ding Y, Liu R, Rong J, et al. Rheological behavior of heat-induced actomyosin gels from yellowcheek carp and grass carp. Eur Food Res Technol, 2012;235:245-51.

44. Lesiów T, Xiong YL. Mechanism of rheological changes in poultry myofibrillar proteins during gelation. Avian Poult Biol Rev 2001; 12:137-49.

45. Sano T, Ohno T, Otsuka-Fuchino H, et al. Carp natural actomyosin: thermal denaturation mechanism. J Food Sci 1994;59: 1002-8.

46. Sankar TV, Ramachandran A. Thermal stability of myofibrillar protein from Indian major carps. J Sci Food Agric 2005;85:5638.

47. Liu R, Zhao S, Regenstein JM, et al. Gelling properties of fish/ pork mince mixtures. J Food Sci 2016;81:C301-7.

48. Xu Y, Xia W, Yang F, et al. Protein molecular interactions involved in the gel network formation of fermented silver carp mince inoculated with Pediococcus pentosaceus. Food Chem 2010;120:717-23. 